\title{
Crebillon, La Nuit et le Moment ou les Matines de Cythère
}

\section{Franco Piva}

\section{(2) OpenEdition}

10 Journals

\section{Édition électronique}

URL : https://journals.openedition.org/studifrancesi/39447

DOI : 10.4000/studifrancesi.39447

ISSN : 2427-5856

Éditeur

Rosenberg \& Sellier

\section{Édition imprimée}

Date de publication : 1 décembre 2004

Pagination : 376-377

ISSN : 0039-2944

\section{Référence électronique}

Franco Piva, "Crebillon, La Nuit et le Moment ou les Matines de Cythère », Studi Francesi [En ligne], 143 (XLVIII | II) | 2004, mis en ligne le 30 novembre 2015, consulté le 19 mai 2021. URL : http://

journals.openedition.org/studifrancesi/39447 ; DOI : https://doi.org/10.4000/studifrancesi.39447

Ce document a été généré automatiquement le 19 mai 2021.

\section{(c) $(1) \&$}

Studi Francesi è distribuita con Licenza Creative Commons Attribuzione - Non commerciale - Non opere derivate 4.0 Internazionale. 


\title{
Crebillon, La Nuit et le Moment ou les Matines de Cythère
}

\author{
Franco Piva
}

\section{RÉFÉRENCE}

CREBILLON, La Nuit et le Moment ou les Matines de Cythère. Edition établie et annotée par

Jean SGARD, Paris, Librairie Génétale Française, 2003 pp. 157.

1 Qui aurait pu espérer ou même oser penser, il y a encore une trentaine d'années, que Crébillon passerait bientôt au Livre de Poche? Certes, bien des choses ont changé depuis l'époque où Crébillon était classé au second rayon; bien des travaux et des analyses de plus en plus raffinés et convaincants ont habitué les lecteurs, même les plus rétifs, à voir dans l'œuvre de Crébillon autre chose que l'œuvre d'un écrivain libertin, au sens où ce terme était entendu au XVIIIe ou même au XIXe siècle. L'édition critique que l'équipe dirigée par Jean Sgard a procurée récemment pour les «Classiques Garnier» est venue consacrer une réhabilitation que Crébillon méritait depuis longtemps aussi bien comme moraliste que, surtout, comme écrivain. La preuve la plus éclatante en est donnée, plus que par les plus célèbres Egarements du cœur et de l'esprit, par La Nuit et le Moment que Crébillon lui-même considérait «ce qu'il a[vait] fait de mieux dans sa vie» et qui pour Jean Sgard «représente le mieux le génie énigmatique de son auteur». Dans une Préface aussi discrète que lucide Sgard offre au lecteur les éléments pour comprendre et apprécier au mieux cette œuvre à laquelle Crébillon a longuement travaillé, et qui nous présente, aussi bien du point de vue du style que du contenu, le Crébillon le plus mûr et le plus intéressant. Le Dossier qui conclut le volume propose quelques textes, tirés des autres œuvres de Crébillon, sur le thème du «moment» et les jugements que les lecteurs «d'hier et d'aujourd'hui» ont portés sur l'ouvrage: les uns et les autres sont très significatifs, d'un côte parce qu'ils nous font comprendre comment le thème fondamantal de l'œuvre qui est proposée à l'attention du public s'insère dans les problématiques affrontées par Crébillon au cours de sa vie d'écrivain, de l'autre côté, parce qu'ils font voir le long parcours qu'il a fallu faire pour 
arriver à comprendre le sens réel d'une œuvre trop souvemt mal lue et pour apprécier les qualités, elles aussi trop souvent méconnues, de l'écriture crébillonnienne, une des plus intéressantes et originales que le XVIIIe siècle ait produites. 